\title{
Participation and the Blurring Values of Journalism
}

\author{
Hujanen, Jaana Kristiina
}

Routledge

2018-09-25

Hujanen , J K 2018 , Participation and the Blurring Values of Journalism . in S Allan , C Carter , S Cushion, L Dencik , I Garcia-Blanco , J Harris , R S , K Wahl-Jorgensen \& A Williams (eds), The Future of Journalism : Risks, Threats and Opportunities . Journalism Studies: Theory and Practice, Routledge, London , pp. 349-358, Participation in the Future of Journalism Conference , Cardiff , United Kingdom , 10/09/2015.

http://hdl.handle.net/10138/338096

unspecified

acceptedVersion

Downloaded from Helda, University of Helsinki institutional repository.

This is an electronic reprint of the original article.

This reprint may differ from the original in pagination and typographic detail.

Please cite the original version. 


\title{
Participation and the Blurring Values of Journalism
}

\section{Jaana Hujanen}

\author{
Introduction
}

News media rely increasingly on citizen journalism and have become dependent on user-generated visibility. These processes mix the relationships between professional journalists and the former audience. The blurring of the practices of producing and using journalism also enhance the reinvention of the occupational ethos of journalism: the values defining journalism and constructing boundaries between journalism and non-journalism. Participatory communication culture makes changes in the values of journalism likely. The journalistic norms and practices connected to the ideal participation are, in many ways, opposite to those of modern journalism. They challenge the socio-cultural rationale for professional control over content creation, filtering and distribution (Deuze 2007, 142-170; Ryfe 2009; Witschge 2012).

The objectivity norm has claimed that journalists are impartial, neutral, fair and credible providers of information (Deuze 2005, 446-447). Journalists are truth-seeking professionals, aiming at factual, accurate, balanced and fair reporting (Tuchman 1978). Ethics refers to the idea of journalists having a specific sense of ethics, validity and legitimacy. The high modern ideal of autonomy refers to a dispassionate and impersonal journalist with an outsider and matter-of-fact perspective. Autonomy presupposes that journalism is independent of economic, political or other efforts of influence. In contrast, participation refers to news as a shared and collaborative practice, and to journalists who listen to and reflect a variety of voices, avoid monology, and stimulate discussion and engagement (Soffer 2009, 474, 487-488).

The research so far has revealed an unresolved interplay between professional control and open participation. While journalists have perceived contact with the audience as being good, they have found participatory culture to be unsettling to the professional paradigm of journalism (Singer 2007; Heinonen 2011). Professional journalists' gatekeeping position vis-à-vis citizen journalists has been reinforced (Singer 2007, 2010; Domingo et al. 2008; Thurman 2008; Soffer 2009; Lewis, Kaufhold, and Lasorsa 2010). The majority of journalists have not regarded citizens' contributions as "proper" journalism, and newsrooms have co-opted participatory practices to suit traditional routines (Wardle and Williams 2010; Örnebring 2013).

However, journalism's ideological commitment to control may be giving way to the hybrid logic of adaptability and openness: a willingness to see audiences on a peer level, to appreciate their contributions, and to find the normative purpose for journalism in transparency and participation (Andén-Papadopoulos and Pantti 2013; Hujanen 2013; Singer 2014). Lewis (2012, 852) challenges researchers to track the contours of the nascent boundary work: how, where and why does the professional logic of control become rearticulated in relation to the participatory logic? 
This article examines the evolution of journalism's values and ethical principles, and analyses how participation is becoming a journalism culture in Finnish news media. The focus is on newspaper journalists' perceptions of the roles and practices of professional journalists and audience/users in journalism. The article examines the blurring of the values of journalism and journalists' ethos against the high modern ideals of journalism (Deuze 2005). Of special interest is how objectivity, autonomy and ethics of journalism are made sense of and reinvented.

The Study in Context

Newspapers face challenges that call for a re-evaluation of the professional ethos and culture of journalism. Since the beginning of the 1990s, Finnish newspapers have underlined audienceoriented policy. News criteria have veered from social importance and public interest to human interest (Hujanen 2008, 2009; Pantti 2009). Dailies have also had projects inspired by public journalism to perceive their audiences as citizens who compose publics and possess legitimacy to participate in the political processes (Ahva 2010). Kantola (2013) describes the change as a development from high modern journalism towards liquid journalism. A liquid modern journalist is flexible, producing content that appeals both to common sense and to emotions, combining the tasks of information transmission, telling stories, raising discussion and entertaining. In media companies' strategy, the notion of "audience participation" has become a key ingredient.

I have conducted 26 in-depth interviews with journalists from Etelä-Suomen Sanomat, Helsingin Sanomat, Metro and Savon Sanomat. Besides the printed paper, their content can be read on the internet and on mobile platforms. Etelä-Suomen Sanomat and Savon Sanomat are regional dailies with circulations of between 49,558 and 52,934 (Levikintarkastus 2014). Helsingin Sanomat has a circulation of 331,551 and is the leading paper in Finland. Even though it has lost subscribers, it has active development work going on. The business of the dailies has been profitable in past years but has sunken rapidly due to lower income from subscriptions and advertising, and problems in achieving gains in digital revenue. Metro is a free paper published five times a week in Helsinki, with a print run of 140,000 .

The first set of interviews was gathered from 2010 to 2011. The second interview data were gathered from 2013 to 2015 in the situation of accelerating technological change, economic pressures, changes in people's media uses and media houses' development of journalism. The dataset includes interviews with (1) personnel dealing with innovation and development work; (2) news management; (3) producers; and (4) journalists. Managerial and development levels shed light on the objectives of change projects while journalists shed light on the everyday work. Only one interview was conducted by telephone; the rest were conducted face-to-face.

A written questionnaire structured the interviews. The themes covered interaction between journalists and readers, and journalists' perceptions about their own role and that of the "audience" in news production. The interviews, lasting about one hour each, were taped and transcribed. 
Participants were requested to give their informed consent and were accorded all due respect, including their anonymity.

Critical discourse analysis (CDA) deals with the social conditions and consequences of language use (Fairclough and Wodak 1997; Wodak 2001). Discourse is defined as language use as social practice and is considered to be a part of the construction of professionalism (Fairclough 1992, 6265; Fairclough and Wodak 1997, 258-259). CDA emphasizes the need to study language use as an inherently social phenomenon within specific historical, cultural and interactional contexts. This means that the reinvention of the ideal and practice of journalism is seen as a local, historical and discursive process.

Journalistic values and practices, from the perspective of CDA, are constructed by drawing on discourses that have prior significations and that are socially available and possible in a particular context. I assume that journalists resort to powerful discourses about "good" journalism; journalists are constrained by these discourses but they also have options in creating, choosing and modifying them. I assume the modern ideals of journalism are present when Finnish journalists imagine new tasks and roles for themselves and for readers.

Within the context of this article, "discourse" refers to the different perspectives representing journalism, its values and its practices. Thus, the discourses occurring in the interviews are regarded as means of representing journalistic values and practices from particular perspectives, and it is assumed that they offer particular roles and tasks for journalists and readers. I have named these: (1) the discourse of professional news production, (2) the discourse of citizen debate; and (3) the discourse of interactive news "produsing".

The Discourse of Professional News Production

For the data gathered in 2010, the discourse of professional news production occupies a hegemonic position. This perspective can be called the discourse of professional news production, because within it, a strong demand for professionally produced journalism is constructed. It suggests that professional skill is a part of "proper" journalism, and that a professional journalist is able to do a better job than the reader. Professional skill is defined as knowledge and experience of the values and ethical principles of journalism. The command of principles of journalism is thus represented as a qualification required of the journalism profession even though journalism in Finland lacks many trappings of a classical profession (each quote shown is from the interview answers given in response to the questionnaire):

If the newspaper thinks that this is the cheap way to produce content and that we take [content] for free from random writers and we replace the professional journalists with them, then it's clearly a threat; it threatens all general principles of journalism and professional production. I have always compared this to the doctor's occupation. If we need a doctor then we, of course, go to see a professional, not to any uneducated quack doctor. This shows well the difference between a 
professional journalist and whoever. Now the prevalent illusion is that "whoever" could sit down and write, but good journalism isn't done with fantasy or from one's own head, sitting and writing whatever comes to mind.

In the discourse, readers are called "audience", "readers", "citizens" or "anyone". Journalism produced by "non-professionals" is thought to threaten the quality of the journalism:

Well, yes, if it [readers' participation] goes too far it is a [threat]. Especially if the same principles [that] journalists follow, aren't followed. At worst, this could take away the credibility, which is the most important for the existence of the newspaper.

An emerging representation questions a reader's skill, experience, knowledge and expertise: a reader is "an average reader", "an unexperienced person", "a random writer" who lacks the capability to produce journalism. Within the discourse, readers write their "own stuff", often on an impulse and out of imagination. There is hardly any reference to competent readership but there is to incompetent, indefinite and loud readership. Moreover, personal experience and local content lack general interest and social significance:

Of course it [reader participation] can be [a threat] because there is always the risk that it leads to that ... journalism will become even more superficial and that only inapplicabilities and quasi problems will come to the top. Then we forget the real problems that might be developing in Finnish society as well ... I think it's wrong, if we think about the most basic task of journalism, as I see it myself, as the watchdog of the power, and as defender of democracy and as protector of fair access to information.

Within this discourse, a reader must be able to separate the content produced by the newsroom. Reader participation is limited to specific sections like letters-to-the-editor and youth pages. In this way, the discourse illustrates the boundary work between "journalism" and "non-journalism":

I think it is quite arguable that journalists are professionals and the readers are readers, that they still have an active letters-to-the-editor section. Readers' articles are maybe not needed on other pages or sections, except for these young people's articles that are quite good ... I think the reader should be able to distinguish what is journalistic content produced by the editorial staff and what is something else.

"Proper" journalism relies in the discourse on the "basic principles of journalism", which are connected to the high modern ideals of actuality, objectivity, public service, autonomy and ethics (Deuze 2005). There emerges a newspaper institution that thinks through the code of journalism's ethics. As perceived in the discourse, "occasional writers" are not aware of their ethical and judicial 
responsibility. The interviewees used the term "objectivity" only seldom, but made suggestions about it. The audience's right to fair information and the journalist's obligation to diverse and independent points of view refer to the value of balanced journalism. In the discourse, "good" and professional journalism is thus defined as non-subjective.

Autonomy is also represented as a cornerstone of professional journalism. Professionalism is portrayed as autonomy from outside forces. Professional journalist's identity as an independent actor is stressed in relation to readers: "Exchanging ideas [with readers] does not harm, but a professional journalist should realize her/his own identity ... to stay an independent author". A restricted role is constructed for the participating readers as professional journalists are portrayed as gatekeepers, and readers are assigned an assisting role under the profession's control: "[As a] last resort, the journalistic right of decision and the fulfilment of stories is up to the editors; it can't be left to the citizens. And it can neither be left to any other quarter". In this discourse, journalism is not made with but for the readers. The authorship of journalism belongs to journalists:

That the readers would start doing our newspaper ... that I find strange. I think it would be better if we did the paper for the readers ... If the content produced by readers increases, then the content produced by journalists decreases. Whose paper is it then, if we now talk about a newspaper?

The Discourse of Citizen Debate

With regard to the evolution of journalism from the viewpoint of reader participation, the discourse of citizen debate indicates how journalistic values have been undergoing reinvention, with new practices negotiated for audiences and citizens. I have named this perspective the discourse of citizen debate in order to illustrate that within it, readers are seen as playing a role in the making of newspapers.

However, as the name of the discourse indicates, content produced by other than professional journalists is not perceived as journalism or even as public/civic journalism but as "citizens' debate", "public discussion" and "communality". The discourse thus contributes to the emerging boundary between journalism and non-journalism and can be seen as a sub-discourse to professional news making: "It isn't journalism any more if we go on to accepting that readers can churn out whatever they like, just like Facebook things, more connected to communities; it's not journalism, it's another thing".

Citizens' debates are portrayed as richness of democracy and multivoicing public discussion: they bring people's voices and faces into the public sphere, and strengthen freedom of expression. However, citizens' debate cannot proceed without journalistic control. Here, the discourse of professional news making intertwines with that of citizen debate: journalists' ethical code of practice is represented as a requirement for debate. Citizens' debate thus has the potential for 
democracy, but journalists voice reservations regarding its representativeness: "Damned elite, those of who were in the local paper, Aamulehti, that wasn't any democratic voice. It was a particular voice of an activist group that you could hear in fact ..." The need to follow journalists' code of practice also stems from the problems that people's voices are thought to generate. In the discourse, the use of raunchy language and pseudonyms, populism and extreme opinions make the debate dynamite. The assumed problems generate a need for moderation, and participation becomes a time-consuming and expensive practice.

The Discourse of Interactive News "Produsing"

Within the discourse of interactive news "produsing", journalism is perceived as a collaborative practice involving both professional journalists and readers. It is seen as a process in which the input and practices of both partners intertwine. Because within this perspective on journalism the practices of producing and using mix, it is called the discourse of interactive news "produsing". As a result, some of the old assumptions about divisions between user material and editorial material are fading.

The discourse started to emerge in 2013 and illustrates a change in journalists' occupational ethos. Interactive practices are represented as a focus of innovation. Digitalization, social media and mobile platforms explain the strengthening of the discourse. The notion of journalism's authorship is represented broadly and the practice of gatekeeping is renegotiated: readers are allowed to participate in the making and distributing of journalism, by providing material, ideas and contacts, comments and sharing journalism produced by professional journalists with other readers:

Traditionally in the editorial office we have been thinking that the journalist is a gatekeeper who guards what is good or what is bad, what is interesting and what is less interesting. I would say that, of course, you have to face new challenges; that we maybe change the former gatekeeper role in a direction that accepts that there is material coming from other places and partners as well, from the readers.

Participating readers were called "helpers", "volunteers" and "a community of local reporters" who provided an additional workforce to pursue better journalism. A community of reporters is allowed to share practices that used to belong to professional journalists only. Some news media studied had developed an application to give journalistic tasks to local reporters. Newsrooms also had a practice of inviting readers to join a Facebook conversation, moderated by the news media.

However, discursive demarcation between the logic and practice of professional journalism and social media is still being reconstructed. What separates the two sides is the ethical code of journalism. It requires professional journalists to separate facts and opinions and strive for nonbiased presentation. Because of this, the difference between "professionally produced journalism" and "citizen journalism" is reconstructed and ideas from readers are perceived as stimuli, which are developed further, or as material that is verified and complemented. 
Unlike in the previously mentioned discourses, reader engagement is represented as professional news media's answer to change in communication culture: people expect that they can have an active role in the making of media. Despite the economic reasons behind reader engagement, which are portrayed as less important, the material produced by the readers has news value especially for a free paper like Metro, which has a small staff and is oriented towards local events.

Metro has done reader engagement in a great way. There is a community of reporters, 150 people, to whom you can give various tasks. They even have an application with which you can send a request if you want ... "Hi, we would like to get pictures of coltsfoots". You get hundreds of pictures from there. They [reader-reporters] are really enthusiastic. We have 30 volunteers in Vantaa. If we send them a message that there is a big local factory building on fire and could someone go and take a picture with a mobile phone, there is always a couple of those who leave right away.

Reader engagement is also represented in the discourse as a tool for collaborative information gathering and crowdsourcing. Helsingin Sanomat has experienced crowdsourcing, and has asked readers to contribute to investigative journalism. Engagement is also connected to customer relationships. Reader participation was seen as important to Metro because readers normally do not commit themselves to free papers. For a leading newspaper, reader engagement represents a tool to bind people to the paper as subscribers and fight against becoming a newspaper of the elite only.

When making the paper we have to listen to citizens and pay attention to them. I think it [participation] enhances readers' loyalty to the paper ... People are more committed to our brand and they feel that Helsigin Sanomat is maybe not that elitist but more human and down to earth. The fear is that [if] the number of paying customers diminishes, Helsingin Sanomat becomes elitist in the end - a paper of a small group — and this is one of the biggest fears we want to avoid.

When readers have a role in the making of journalism, the demarcation between news media and social media becomes blurred. Journalists from Metro described their paper as a semi-social form of media, which has characteristics of both social media and traditional news media:

Well, Metro has been called as semi-social media, it has characteristics of social media, the group of reader-reporters is like a community, they remember our phone number or that Metro publishes their pictures, but still there is the professional newsroom, on the other side.

Being a semi-social form of media means that professional journalists see their task as being available to readers, to listen to them and to communicate with them. In the emerging discourse, journalists position themselves within and among the audience. The new roles and practices of the audience also affect how the ideals of public service and autonomy are renegotiated. Relevance for 
the readers and popularity among them have become criteria in the evaluation of quality. The newsrooms have developed an index to measure which stories are clicked, how much time is spent reading them and if they are shared, illustrating how quality is redefined by the value the stories have in an online context.

Moreover, within this discourse, professional journalism is seen as being dependent on how it is consumed and promoted in social media. Whether the stories produced by professional journalists are clicked, liked, linked and shared is seen as vital for professional news media. Instead of being the target group and users, readers act as secondary gatekeepers and thus produce journalism. This is a profound change to the logic of autonomy; it becomes shared.

Conclusion

I have examined the evolution of journalism's values and ethical principles, analysing how participation is becoming a part of the professional journalism culture in Finland. I have analysed the discourses of (1) professional news production; (2) citizen debate; and (3) interactive news "produsing". The partially competing and contradictory discourses show that the values of journalism are evolving.

The first two discourses construct a clear boundary between journalism and non-journalism; between journalism and citizens' debate; and between professionals and amateurs. In this perspective, authorship of journalism belongs to the professionals. Even though there is no formal education requirement for the journalism profession in Finland, expertise and knowledge of the principles of journalism is represented as a qualification to participate in the making of journalism. Following this, content produced in line with the high modern practices is perceived as trustworthy and unbiased, and content produced outside the newsroom in principle is problematic.

In the first two discourses, journalists see it as their task to control the supposed high quality of content (Singer 2005, 2007, 2010; Domingo et al. 2008, 339-340; Thurman 2008; Heinonen 2011). This indicates that the way journalists renegotiate journalistic values reflects the high modern perception of autonomous journalism: a journalist follows the professional code of practice, and is just and independent from outside efforts of influence. A journalist is thus represented as a gatekeeper towards economic and political spheres of influence and citizens.

Soffer $(2009,473-474)$ argues that objectivity and participation or dialogue belong to distinct journalistic cultures on the basis that it is "hard to believe that they would be integrated on a regular basis". Participation and objectivity, with their distinctive world views, do differ. This study, however, reveals a pattern of integration in the complex relationship of high modern values and the idea of participation. The discourse of professional news making affects how the new roles of the journalists and the public is imagined, but the discourse of professional news making is also challenged by the discourse of interactive news "produsing". 
The merging of those values can be seen in the discourse of the citizen debate, which constructs an ideal of moderated conversation or controlled polyphony in journalism (Soffer 2009). To ensure "quality" fact checking, distinguishing between professional and "amateurish" efforts, as well as moderating the discussions, were perceived as central. In the discourse of interactive news "produsing", the values of journalism evolve towards openness and transparency. Journalism is perceived as a collaborative practice between professional journalists and readers; it is a process in which the input of both partners intertwine. Readers are negotiated an assisting role based on the terms of the profession's principles. Even though the logic of control changes, discursive demarcation between the values and practice of professional journalism and social media are reconstructed. What separates the two sides are the values and the ethical code of professional journalists.

The value of objectivity is important for journalists because it helps them to protect themselves against criticism and allegations of manipulation (Schudson 2001, 165). The discursively constructed need for gatekeeping can also be interpreted as a means to maintain their exclusive power of control. Therefore, the requirement of control illustrates how professional power and authority operate (Hermida and Thurman 2008; Schudson and Anderson 2009).

The values of objectivity, actuality and autonomy are also updated to the context of participatory media. Within the third discourse, journalists allow readers a role as local reporters to provide topical information on local events or as experts in assisting with crowdsourcing and investigative journalism. Professional journalism is seen as being dependent on how it is consumed and shared in social media. As readers get a role as secondary gatekeepers (Singer 2014), autonomy is being reinvented as a shared practice.

\section{REFERENCES}

Ahva, Laura. 2010. Making News with Citizens. Public Journalism and Professional Reflexivity in Finnish Newspapers. Tampere: Tampere University Press.

Andén-Papadopoulos, Kari, and Mervi Pantti. 2013. "Re-imagining Crisis Reporting: Professional Ideology of Journalists and Citizen Eyewitness Images.” Journalism 14 (7): 960-977. doi: $10.1177 / 1464884913479055$

Deuze, Mark. 2005. "What is Journalism? Professional Identity and Ideology of Journalists Reconsidered." Journalism. Theory, Practice \& Criticism 6 (4): 442-464. doi:

$10.1177 / 1464884905056815$

Deuze, Mark. 2007. Media Work. Cambridge: Polity.

Domingo, David, Thorsten Quandt, Ari Heinonen, Steve Paulussen, Jane B. Singer, and Marina Vujnovic. 2008. "Participatory Journalism Practices in the Media and Beyond." Journalism Practice 2 (3): 326-342. doi: 10.1080/17512780802281065 [Taylor \& Francis Online], 
Fairclough, Norman. 1992. Discourse and Social Change. Cambridge: Polity Press.

Fairclough, Norman, and Ruth Wodak. 1997. "Critical Discourse Analysis. An overview." In Discourse Analysis: A Multidisciplinary Introduction, edited by Teun A. van Dijk, 258-284. London: Sage.

Heinonen, Ari. 2011. "The Journalist's Relationship with Users: New Dimensions to Conventional Roles." In Participatory Journalism. Guarding Open Gates at Online Newspapers, edited by Jane Singer, Alfred Hermida, David Domingo, Ari Heinonen, Steve Paulussen, Thorsten Quandt, Zvi Reich, and Marina Vujnovic, 34-55. Chichester: Wiley-Blackwell.

Hermida, Alfred, and Neil Thurman. 2008. "A Clash of Cultures. The Integration of Usergenerated Content within Professional Journalistic Frameworks at British Newspaper Websites." Journalism Practice 2 (3): 343-356. doi: 10.1080/17512780802054538

Hujanen, Jaana. 2008. "RISC Monitor Audience Rating and its Implication for Journalistic Practice.” Journalism. Theory, Practice, Criticism 9 (2): 182-199. doi: 10.1177/1464884907086874

Hujanen, Jaana. 2009. 'Informing, Entertaining, Empowering. Finnish Press Journalists' (Re)negotiation of their Tasks." Journalism Practice 3 (1): 30-45. doi: $10.1080 / 17512780802560724$

Hujanen, Jaana. 2013. "At the Crossroads of Participation and Objectivity. Reinventing Citizen Engagement in the SBS Newsroom.” New Media and Society 15 (6): 947-962. doi: $10.1177 / 1461444812460721$

Kantola, Anu. 2013. "From Gardeners to Revolutionaries: The Rise of Liquid Ethos in Journalism.” Journalism 14 (5): 606-626. doi: 10.1177/1464884912454504

Lewis, Seth C. 2012. "The Tension between Professional Control and Open Participation: Journalism and its Boundaries.” Information, Communication \& Society 13 (1): 836-866. doi: 10.1080/1369118X.2012.674150

Lewis, Seth C., Kelly Kaufhold, and Dominic L. Lasorsa. 2010. "Thinking about Citizen Journalism.” Journalism Practice 4 (2): 163-179. doi: 10.1080/14616700903156919

Levikintarkastus 2014. Kansallinen Mediatutkimus, Levikintarkastus [National Newspaper Circulation Audit]. Helsinki: MediaAuditFinland Oy.

Örnebring, Henrik. 2013. "Anything You Can Do, I Can Do Better? Professional Journalists on Citizen Journalism in Six European Countries." The International Communication Gazette 75 (1): 35-53. doi: 10.1177/1748048512461761

Pantti, Mervi. 2009. "Tunteellisempaa journalismia [More emotional journalism].” In Journalismi murroksessa [Changing Journalism], edited by Esa Väliverronen, 193-206. Helsinki: Gaudeamus.

Ryfe, David. 2009. "Structure, Agency and Change in an American Newsroom.” Journalism 10 (5): 665-683. doi: 10.1177/1464884909106538

Schudson, Michael. 2001. "The Objectivity Norm in American Journalism.” Journalism. Theory, Practice \& Criticism 2 (2): 149-170. doi: 10.1177/146488490100200201 
Schudson, Michael, and Chris Anderson. 2009. "Objectivity, Professionalism, and Truth Seeking in Journalism.” In The Handbook of Journalism Studies, edited by Karin Wahl-Jorgensen and Thomas Hanitzsch, 88-101. New York: Routledge.

Singer, Jane B. 2005. “The Political J-blogger. Normalizing' a New Media Form to Fit Old Norms and Practices.” Journalism. Theory, Practice \& Criticism 6 (2): 173-198. doi:

$10.1177 / 1464884905051009$

Singer, Jane B. 2007. "Contested Autonomy: Professional and Popular Claims on Journalistic Norms.” Journalism Studies 7 (1): 2-18. doi: 10.1080/14616700500450277 [Taylor \& Francis Online],

Singer, Jane B. 2010. "Quality Control: Perceived Effects of User-generated Content on Newsroom Norms, Values and Routines.” Journalism Practice 4 (2): 127-142. doi: $10.1080 / 17512780903391979$

Singer, Jane B. 2014. "User-generated Visibility: Secondary Gatekeeping in a Shared Media Space." New Media and Society 16 (1): 55-73. doi: 10.1177/1461444813477833 [Crossref], [Web of Science $®]$,

Soffer, Oren. 2009. "The Competing Ideals of Objectivity and Dialogue in American Journalism." Journalism. Theory, Practice \& Criticism 10 (4): 473-491. doi:

$10.1177 / 1464884909104950$

Thurman, Neil. 2008. "Forums for Citizen Journalists? Adoption of User Generated Content Initiatives by Online News Media." New Media and Society 10 (1): 139-157. doi:

$10.1177 / 1461444807085325$

Tuchman, Gay. 1978. Making News - A Study in the Construction of Reality. New York: The Free Press.

Wardle, Claire, and Andy Williams. 2010. "Beyond User-Generated Content: A Production Study Examining the Ways in which UGC is Used at the BBC." Media, Culture \& Society 32 (5): 781-799. doi: 10.1177/0163443710373953

Witschge, Tamara. 2012. "Changing Audiences, Changing Journalism.” In Changing Journalism, edited by Peter Lee-Wright, Angela Phillips, and Tamara Witschge, 117-134. London: Routledge.

Wodak, Ruth. 2001. "What CDA is about - A Summary of its History, Important Concepts and its Developments." In Methods of Critical Discourse Analysis, edited by Ruth Wodak and Michael Meyer, 1-13. London: Sage. 